\title{
Pendidikan Akhlak dalam Lingkungan Keluarga Menurut Imam Ghazali
}

\author{
SHOLEH \\ Fakultas Agama Islam (FAI) Universitas Islam Riau (UIR) Pekanbaru \\ Jl. Kaharuddin Nasution, No. 113 Perhentian Marpoyan Pekanbaru 28284 \\ Telp : 081319952829 email : sholeh@yahoo.co.id
}

\begin{abstract}
Abstrak: Penilaian baik dan buruknya seseorang sangat ditentukan melalui akhlaknya. Akhir-akhir ini kerusakan akhlak generasi muda tanpa kecuali para mahasiswa dan pelajar dengan segala jenis dan bentuknya adalah sebuah ancaman yang berbahaya tidak saja terhadap para pelakunya, tapi merupakan ancaman yang serius terhadap stabilitas sosial, ekonomi dan keamanan serta kesatuan bangsa. Untuk membentuk akhlak yang mulia, hendaknya penanaman akhlak terhadap anak digalakkan sejak dini, karena pembentukkannya akan lebih mudah dibanding setelah anak tersebut menginjak dewasa. Al-Ghazali merupakan seorang tokoh dan ulama besar yang memiliki corak pemikiran yang unik sebagaimana terlihat dari perkembangan pemikirannya. Al-Ghazali juga banyak mengulas tentang pendidikan akhlak. Lingkungan keluargalah menurut Imam Al-Ghazali yang sangat dominan dalam membina pendidikan akhlak, karena anak yang berusia muda dan kecil itu lebih banyak di lingkungan keluarga dari pada di luar. Oleh karena itu, artikel ini mencoba untuk menguraikan urgensi pendidikan akhlak di lingkungan keluarga dalam perspektif Imam Al-Ghazali.
\end{abstract}

Kata Kunci : Pendidikan Akhlak, Lingkungan Keluarga, Imam Al-Ghazali

\section{PENDAHULUAN}

Pada masa dua tahun terakhir ini kerusakan akhlak tidak lagi sekedar tawuran, tapi telah lebih parah lagi. Mahasiswa dan pelajar (sampai tingkat Sekolah Dasar) telah diracuni oleh narkoba. Suatu hal yang mungkin dulu tidak pernah terbayangkan. Bahkan banyak di antara mereka yang sudah sampai kepada kecanduan yang sudah sangat sulit diobati. Ini baru beberapa kerusakan akhlak yang telah terlanjur diekspos kehadapan publik. Adapun kerusakan akhlak yang tersembunyi yang tidak atau belum terdeteksi tentunya lebih parah lagi. Seperti pelacuran dikalangan mahasiswa dan mahasiswi, pornografi dengan berbagai jenis dan bentuknya, pemalsuan ijazah, kerusakan akhlak dikalangan para pendidik sendiri dan lain sebagainya.

Kita tidak memungkiri adanya faktor eksternal yang sangat kuat yang menyebabkan kondisi ini. Tapi minimal ini merupakan indikator yang sangat nyata betapa jeleknya kondisi internal mereka (baca pendidikan dengan segala isinya). Karena apa yang mereka pelajari dan siapa yang mengajari mereka sudah tidak mampu lagi memberikan imunitas kepada mereka dari bahaya-bahaya luar. Sehingga ketika mereka dirasuki oleh "racunracun" eksternal mereka terkapar tak berdaya digerogoti oleh "racun" tersebut.

Kerusakan akhlak para mahasisiwa dan pelajar dengan segala 
jenis dan bentuknya adalah sebuah ancaman yang berbahaya tidak saja terhadap para pelakunya, tapi merupakan ancaman yang serius terhadap stabilitas sosial, ekonomi dan keamanan serta kesatuan bangsa. Atau dengan kata lain dapat merongrong integritas suatu bangsa. Beberapa fenomena di atas kiranya cukup menjadi alasan yang kuat untuk melakukan reformasi pendidikan dalam berbagai bidang. Jika pendidikan di negara-negara maju yang telah memberikan banyak kontribusi positif untuk kehidupan manusia di seluruh dunia tidak lepas dari pembaruan dari waktu ke waktu, maka pendidikan di Indonesia yang pada masa belakangan ini masih belum menemukan format yang produktif tentunya sangat mendesak sekali untuk diperbaharui.

Mengapa itu semua bisa terjadi? Jawabanya tentu saja sangat kompleks, tetapi yang pasti berbagai perilaku yang terjadi pada sikap dan perilaku anak bangsa saat ini tidak dapat dilepaskan dari pendidikan akhlak yang telah dan disajikan bagi anak bangsa.

Lebih jauh, pendidikan akhlak tidak terlepas dari pendidikan agama yang keduanya harus dilaksanakan dalam praktek hidup, pengalaman sehari-hari perlakuan dan percontohan di samping pengertian tentang agama dan moral. (Darajat, 1976: 24) Oleh karena itu, urgensi pendidikan akhlak atau moral dalam pendidikan pada umumnya, dan pendidikan Islam pada khususnya, dan terlebih lagi dalam pendidikan di lingkungan keluarga, tetap menjadi persoalan yang perlu diperhatikan, sehingga masyarakat Islam tidak terjebak pada pola-pola pendidikan modern yang hanya mengandalkan kemajuan-kemajuan yang bersifat rasional dan material belaka, dengan mengesampingkan nilai- nilai yang bersifat moral. (Held, 1991: 25)

Dari pernyataan di atas, nampak bahwa pendidikan budi pekerti (akhlak/moral) harus menjadi jiwa dari pendidikan Islam. Karena mencapai budi pekerti yang sempurna adalah merupakan tujuan sebenarnya dari pendidikan. Selain daripada itu, budi pekerti merupakan aspek fundamental dalam kehidupan seseorang, masyarakat maupun negara. Hal ini dipertegas oleh Harun Nasution bahwa tujuan utama dari ajaran-ajaran Islam adalah membina manusia yang mempunyai budi pekerti luhur, di samping mempunyai ilmu.(Nasution, 1999:7).

Adapun di antara beberapa tokoh cendekiawan muslim yang mengedepankan pendidikan akhlak adalah Imam Al-Ghazali. Al-Ghazali merupakan seorang tokoh dan ulama besar yang memiliki corak pemikiran yang unik sebagaimana terlihat dari perkembangan pemikirannya. Pada mulanya Imam Al-Ghazali mendalami ilmu kalam, tetapi karena ilmu ini dianggap tidak mampu mencapai kebenaran hakiki maka dia beralih mendalami filsafat. Al-Ghazali juga banyak mengulas tentang pendidikan akhlak. Oleh karena itu dalam artikel ini penulis mencoba untuk mengungkapkan bagaimana pandangan Imam Al-Ghazali tentang urgensi pendidikan akhlak di lingkungan keluarga.

Secara sistematis, tulisan ini akan membicarakan tentang biografi Imam Al-ghazali, karya-karyanya dan perspektifnya tentang urgensi pendidikan akhlak di lingkungan keluarga. 


\section{RIWAYAT SINGKAT IMAM AL- GHAZALI \\ Kelahiran dan Pendidikan}

Imam Al-Ghazali nama lengkapnya adalah Abu Hamid Muhammad bin Muhammad bin Muhammad bin Ahmad al-Tusi al Syafi'i.(Ahmad, 1975:28) Ia mendapat gelar Imam Besar Abu Hamid Imam Al-Ghazali Hujjatul Islam. Imam Al-Ghazali lahir pada tahun $450 \mathrm{H}$ (1058 M) di sebuah kampung bernama Gazaleh (Ghazalah), Thus (Thusia), suatu kota di Khurasan, Persia, atau Iran sekarang. (Amien, 1983: 49) Kota Thus adalah salah satu kota di wilayah Khurasan yang senantiasa diwarnai oleh perbedaan paham keagamaan. Agama yang di anut oleh mayoritas penduduk adalah Islam aliran Sunni, namun di samping itu banyak pula pemeluk Islam Syi'ah dan umat Kristiani.

Dirunut dari garis keturunannya, Imam Al-Ghazali merupakan keturunan Persia dan mempunyai hubungan keluarga dengan raja-raja Saljuk yang memerintah daerah Khurasan, Jibal, Irak, Jazirah, Persia dan Ahwaz. Ayahnya bernama Muhammad adalah seorang penenun dan mempunyai toko tenun di kampungnya. Penghasilan ayahnya tergolong sangat kecil sehingga keluarganya hidup dalam keadaan sangat kekurangan. Meskipun hidupnya sangat miskin, ayahnya adalah seorang pecinta ilmu yang bercita-cita tinggi. Ia adalah seorang muslim yang saleh, yang sangat taat menjalankan agama. Pola kehidupan dan semangat keagamaan dari sang ayah inilah yang turut mewarnai keluarga dan berpengaruh besar terhadap pola hidup dan pola pikir Imam Al-Ghazali. Ayahnya selalu berdoa, agar Tuhan menganugerahi putra yang berpengetahuan luas dan berilmu yang banyak. (Zainuddin, 1991:7)
Sepeninggal ayahnya, Imam AlGhazali diasuh dan dibimbing oleh ibunya. Kasih sayang sang ibu merupakan modal utamanya, yang selalu menjadi pendorong moril bagi mereka untuk belajar terus. Tentang pendidikan, sebelum meninggal dunia, sang Ayah sempat menitipkan kedua anaknya (seorang di antaranya adalah Muhammad, yang kemudian dijuluki Imam Al-Ghazali), kepada sahabat karibnya yang seorang sufi bernama Ahmad bin Muhammad al-Razikani. (Kholiq, 1999:84) Sang ayah sempat pula mengungkapkan kalimat bernada menyesal: "Nasib saya sangat malang, karena tidak mempunyai ilmu pengetahuan, saya ingin supaya kemalangan saya dapat ditembus oleh kedua anakku ini. Peliharalah mereka dan pergunakanlah sampai habis harta warisan yang aku tinggalkan ini untuk mengajar mereka." (Zainuddin, 1991:7)

Setelah harta peninggalan ayahnya habis terpakai, tidaklah mungkin bagi sang sufi itu untuk memberi nafkah kepada mereka berdua, sang sufi pun berkata: "Ketahuilah bahwa saya telah membelanjakan bagi kalian, seluruh harta peninggalan ayahmu. Saya seorang miskin dan bersahaja dalam hidupku. Saya kira hal yang terbaik yang dapat kalian lakukan ialah masuk ke dalam sebuah madrasah sebagai murid. Dengan jalan ini kalian akan mendapatkan makan untuk kelangsungan hidupmu." (Zainuddin, 1991:8)

Kedua anak tersebut berlaku demikian dan ini menjadi sebab dari kebahagian dan tercapainya cita-cita luhur mereka.Di dalam madrasah tersebut, Imam Al-Ghazali (seorang dari dua anak yang dititipkan tersebut) selain mempelajari ilmu fikih, juga dan mempelajari ilmu tasawuf kepada Yusuf An-Nasaj, sampai pada usia 20 tahun. 
Pendidikan dasar tersebut didapatinya di kota kelahirannya, Thus. (Madjidi, 1997: 79)

Setelah itu, Imam Al-Ghazali pergi ke Jurjan dan belajar pada Imam Abu Nasr al-Isma'ili. Dari Jurjan Imam AlGhazali kembali ke Thus dan terus pindah ke sebuah kota bernama Naisabur. Di kota ini Imam Al-Ghazali memasuki Sekolah Tinggi Nizhamiyah, dan di sinilah ia bertemu yang selanjutnya berguru dan bergaul dengan Imam Haramain. (Dahlan, 2000:202) Imam al-Haramain bernama lengkap Abi al-Ma'ali al-Juwaini (w. 1016 M) merupakan ahli fikih Syafi'iah pada waktu itu. (Madjidi, 1997: 79) Guru Imam Al-Ghazali tersebut dipercaya oleh Perdana Menteri Nizamul Mulk untuk menjadi Rektor/ Presiden dari Madrasah (Universitas) Nizhamiyah di Naisabur. Kepada Imam al-Haramain inilah Imam Al-Ghazali diakui dapat mengimbangi keahlian gurunya. (Syafi'I, 1992: 11) Kepada Imam al-Haramain ini, Imam Al-Ghazali belajar ilmu kalam, ilmu ushul, madzab fikih, retorika, logika, tasawuf dan filsafat. (Ibnu Rusn, 1998:11).

Sejak kecil, Imam Al-Ghazali dikenal sebagai seorang anak pencinta ilmu pengetahuan dan sangat gandrung mencari kebenaran yang hakiki, sekalipun diterpa duka cita, dilanda aneka rupa dan nestapa serta dilamun sengsara. Dalam sebuah karyanya ia mengisahkan: "Kehausan untuk mencari hakikat kebenaran sesuatu sebagai habit dan favorit saya sejak kecil dan masa mudaku adalah merupakan insting dan bakat yang dicampakkan Allah swt. Pada temparamen saya, bukan merupakan usaha dan rekaan saja." (Zainuddin, 1991: 9)

Berbekal ilmu yang telah dimilikinya, Imam Al-Ghazali memulai karirnya dari dunia pendidikan. Imam
Al-Ghazali mulai terjun ke dunia pendidikan sebagai pendidik dan memuncak kepada profesi pemikir. Pada tahun 475 H., dalam usia 25 tahun Imam Al-Ghazali mulai menjadi dosen di Universitas Nizhamiyah di Naisabur, di bawah pimpinan gurunya Imam Haramain yang juga pendidik di universitas tersebut. Imam Al-Ghazali dipercayai oleh gurunya untuk mengganti kedudukannya sebagai Maha Guru maupun sebagai Presiden Universitas (Rektor). Hal itu telah mengangkat namanya begitu tinggi. (Zainuddin, 1991: 11)

Setelah gurunya al-Juwaini wafat beliau meninggalkan kota Naisabur menuju ke sebuah kota bernama "alAskar" yang letaknya tidak jauh dari kota Naisabur. Di tempat ini Imam AlGhazali bertemu dengan Wazir Nizamul Mulk, Wazir dari Sultan Malik Syah alSaljuqi. Pada waktu itu, beberapa ulama terkemuka bersama-sama dengan Wazir. Dalam kesempatan ini mereka bersepakat mengadakan tukar pikiran, diskusi-diskusi ilmiah dengan imam Imam Al-Ghazali. Dalam pertemuanpertemuan ilmiah tersebut tampak keunggulan dan kelebihan Imam AlGhazali.

Perdana menteri Nizam Al-Mulk tertarik pada kealiman Imam Al-Ghazali dan kemudian mengangkatnya menjadi Guru Besar di Madrasah Nizhamiyyah, yang didirikan Nizam Al-Mulk di Baghdad pada tahun $484 \mathrm{H} / 1095 \mathrm{M}$, (Abdullah, 2002: 28) suatu Universitas yang mahasiswanya kebanyakan para ulama. Pada masa itu, Baghdad menjadi termasyur sebagai kota ilmu pengetahuan yang didatangi para mahasiswa dari segenap penjuru negeri. (Madjidi, 1997: 80)

Imam Al-Ghazali yang di mata raja merupakan gunung ilmu yang tinggi itu, oleh Raja Saljuk Malik Syah diberi tempat tinggal di apartemen istana 
kerajaan yang mewah, dan diberi gaji yang banyak sebagai Mufti kerajaan Saljuk. Raja memberinya jubah kenegaraan sehingga pengaruh Imam Al-Ghazali melebihi para amir dan menteri. Pekerjaan itu kemudian ditinggalkannya pada tahun $488 \mathrm{H}$, untuk menuju Damsyik dan di kota ini ia merenung, membaca dan menulis selama kurang lebih dua tahun, dengan tasawuf sebagai jalan hidupnya. (Hanafi, 1976: 197).

Dari kota Damsyik ia pindah ke Palestina pada tahun $490 \mathrm{H} / 1098 \mathrm{M}$, dan di sini pun ia tetap merenung, membaca dan menulis dengan mengambil tempat di Masjid Baitu Maqdis. Setelah itu bergeraklah hatinya untuk menunaikan ibadah haji, dan pulang ke negeri kelahirannya hingga wafat.

Akan tetapi sebelum kewafatannya, Fakhr Al-Mulk, Putra Nizam Al-Mulk, dan wazir Sanjar, penguasa Saljukiah di Khurasan, menekan Imam Al-Ghazali untuk kembali ke kerja akademik. Dia menyerah atas penekanan itu dan Imam Al-Ghazali pun mengajar lagi di Nizamiyah di Naisabur. Selang berapa lama akhirnya Imam Al-Ghazali kembali berhenti mengajar dan kembali ke Thus. (Abdullah, 2002: 29) Dari sini tampak bahwa Imam Al-Ghazali sangat concern dengan profesi kependidikannya (akademis) yakni sebagai pendidik dan sebagai pemikir.

Setelah mengabdikan diri untuk ilmu pengetahuan dalam kurun waktu berpuluh-puluh tahun dan setelah memperoleh kebenaran yang hakiki pada akhir hidupnya, Imam Al-Ghazali meninggal dunia di Thus pada 14 Jumadil Akhir 505 H/ 19 Desember 1111 M, di hadapan adiknya, Abu Ahmadi Mujidduddin. Pada masa-masa akhir kehidupannya beliau menempuh jalan sufi. Imam Al-Ghazali memiliki empat orang anak, yakni 3 orang anak perempuan dan seorang anak laki-laki yang bernama Hamid, namun sayang anaknya yang laki-laki tersebut telah meninggal semenjak kecil sebelum wafatnya (Imam Al-Ghazali), karena anak inilah, ia digelarkan "Abu Hamid" (bapak si Hamid). (Imam Syafi'I, 10).

\section{Karya-Karya Ilmiah Imam Al-Ghazali}

Imam Al-Ghazali merupakan seorang pemikir besar, yang banyak melahirkan karya tulis. Penguasaan atas ilmu-ilmu yang dimilikinya, dibuktikan secara kuat lewat buku yang telah ditulisnya. Sebagai seorang intelektual produktif, Imam Al-Ghazali banyak menuliskan karya-karya ilmiah. Karyakarya sang imam berjumlah kurang lebih 134 judul. Karya-karya ilmiah Imam Al-Ghazali tersebut terdapat dalam berbagai bidang ilmu pengetahuan antara lain: tasawuf, akhlak, filsafat, fikih, tafsir, ushul fikih, bidang ilmu kalam, otobiografinya dan lain-lain. (Abdullah, 2002: xx)

Kitab Ihya' 'Ulum al Din merupakan karya emas Imam AlGhazali yang memadukan pemikiran fiqhiyah dengan pemikiran tasawuf dalam satu gagasan yang utuh. Karena spesifiknya karya ini maka para sarjana kontemporer menyebutnya sebagai kitab Fiqih Sufistik. (Abdullah, 2002: xx)

Pendapat lain tentang hasil karya ilmiah Imam Al-Ghazali sebagaimana dikemukakan oleh Asmaran As, dengan mengutip pendapat Al Zabidi sang kritikus kitab Ihya' menuturkan bahwa jumlah karya tulis Imam Al-Ghazali tidak kurang dari 89 kitab. Sampai sekarang tetap terjadi simpang siur mengenai beberapa banyak jumlah karya ilmiah beliau. Di sisi lain, kesimpangsiuran itu justru semakin mempertegas bahwa beliau memang tokoh intelektual yang sangat 
produktif membuat karya ilmiah. Karya-karya ilmiah beliau dapat dikelompokkan sebagai berikut:

Pertama, dalam bidang Filsafat, di antaranya adalah: Maqasid al-Falasifah (Tujuan Para Filosof), Tahafut AlFalasifah (Kerancuan Para Filosof), AlMa'ariful 'Aqliyah, dan Mi'yarul 'Ilmi.

Kedua, dalam bidang Ilmu Kalam, di antaranya adalah: Al-Iqtishad fi AlI'tiqad (Moderasi dalam Aqidah), $A r$ Risalatul Qudsiyah, Qawa'idul Aqaid, dan Iljamul Awwam 'An 'Ilmil-Kalam (Menghalangi Orang Awwam dari Ilmu Kalam).

Ketiga, dalam bidang Ilmu Akhlak dan Tasawuf, di antaranya:, Ihya 'Ulumuddin (Menghidupkan Kembali Ilmu-ilmu Agama), Mizanul Amal (Timbangan Amal), Kimiyaus Sa'adah (Kimia Kebahagiaan), Misykatul Anwar (Relung-relung Cahaya), Minhajul 'Abidin (Pedoman Beribadah), AdDararul Fakhirah fi Kasyfi Ulumil Akhirah (Mutiara Penyingkap Ilmu Akhirat), Al-'Ainis Fil Wahdah (Lembutlembut dalam Kesatuan), Al-Qurbah Ilallahi Azza Wa Jalla (Mendekatkan Diri Kepada Allah), Akhlah Al-Abrar Wan Najat Minal Asrar (Akhlak yang luhur dan Menyelamatkan dari Keburukan), Bidayatul Hidayah (Permulaan Mencapai Petunjuk), AlMabadi Wal Ghayyah (Permulaan dan Tujuan), Talbis Al-Iblis (Tipu Daya Iblis), Nashihat Al-Mulk (Nasihat untuk Rajaraja), Al-'Ulum Al Laduniyyah (Ilmu-ilmu Laduni), Al-Risalah al-Qudsiyah (Risalah Suci), Al-Ma'khadz (Tempat Pengambilan), dan Al-Amali (Kemuliaan).

Keempat, dalam bidang Ilmu Fikih dan Ushul Fikih, di antaranya adalah: Al-Wasith (Perantara), Al-Wajiz (Suratsurat Wasiat), Al-Bastih (Pembahasan yang Mendalam), Khulashatul Mukhthasar (Intisari Ringkasan Karangan), Al-Mustasyfa (Pilihan), AlMankhul (Adat Kebiasaan), Syifakhul
'Alil Fi Qiyas Wa Ta'lil (Penyembuh yang Baik dalam Qiyas dan Ta'lil), dan AdzDzari'ah ila Makarimis Syari'ah (Jalan Kepada Kemuliaan Syari'ah).

Kelima, dalam bidang ilmu tafsir, beberapa karyanya yang di antaranya adalah: Yaaquutut Ta'wil Fi Tafsirit Tanzil (Metodologi Ta'wil di dalam Tafsir yang Diturunkan), dan Jawahir Al-Qur'an (Rahasia yang Terkandung dalam Al-Qur'an),

Keenam, dalam bidang-bidang lainnya, diantarnya: Al Mustahziri (Penjelasan-penjelasan), Hujjatul Haq (Argumen yang Benar), Mufassilul Khilaf, Ad-Darj, Al-Qishasul Mustaqim (Jalan Untuk Mengatasi Perselisihan Pendapat), Fathihatul Ulum, At-Tibrul Masbuk fi Nasihatul Mulk dan Sulukus Sultaniyah. (Asmaran, 1994: 327)

Selain karya-karya tersebut, sebenarnya terdapat juga karya-karya Imam Al-Ghazali yang lain, hanya saja menurut Zainuddin karya-karya yang telah disebutkan di atas, dianggap telah dapat mewakili kitab-kitab karangan Imam Al-Ghazali yang musnah, hilang ataupun yang belum ditemukan. (Zainuddi, 1991: 21).

\section{PENDIDIKAN AKHLAK DALAM LINGKUNGAN KELUARGA DAN PEMIKIRAN IMAM AL-GHAZALI Pendidikan Akhlak}

Keluarga adalah ikatan laki-laki dan wanita berdasarkan hukum atau undang-undang perkawinan yang sah. Di dalam keluarga ini lahirlah anakanak. Dalam keluarga pula terjadi interaksi pendidikan. Para ahli pendidikan umumnya menyatakan pendidikan di lembaga ini merupakan pendidikan pertama dan utama. Dikatakan demikian karena di lembaga ini anak mendapatkan pendidikan untuk pertama kalinya. Di samping itu, pendidikan di sini (keluarga) 
mempunyai pengaruh yang dalam terhadap kehidupan peserta didik di kemudian hari, karena keluarga secara umum merupakan tempat, di mana anak didik menghabiskan sebagian besar waktunya sehari-hari. (Zakaria, 2000: 99)

Keluarga adalah satu-satunya situasi yang pertama dikenal anak, baik prenatal maupun postnatal. Dan ibulah yang pertama kali dikenalnya. Kedekatan ibu dengan anaknya terutama pada masa-masa bayi adalah sesuatu yang alamiah, yang dimulai dari proses reproduksi sampai dengan penyusuan dan pemeliharaan bayi. (Fuaduddin TM, 1999: 22) Oleh karena itu tidak terlalu melebihkan kenyataan kalau dikatakan bahwa ibulah yang mewarnai anak-anaknya. Akan tetapi bukan berarti peran ayah dalam pendidikan anak terabaikan sama sekali. Dalam banyak hal, ayah dapat mengambil peran langsung dalam mendidik anak dalam lingkungan keluarga. Bimbingan akan akhlak anak dalam bersikap, bertindak, dan berkomunikasi bisa dilakukan langsung oleh sang ayah, antara lain dengan memberikan contoh secara terus menerus dalam kehidupan sehari-hari. (Fuaduddin TM, 1999: 23-24)

Dalam keluarga ideal, hubungan ibu-ayah dan anak-anaknya berlandaskan kasih sayang, direalisasikan dalam bentuk memenuhi segala kebutuhannya baik secara rohani, misalnya; perlindungan, belaian, pelukan, juga kebutuhan jasmaninya, misalnya: pakaian, makanan, alat permainan, alat-alat sekolah, dan alatalat yang diperlukan dalam masa puber. Kasih sayang yang diterimanya dari orang tuanya menimbulkan rasa aman pada anak. Rasa aman ini sangat penting bagi perkembangan anak. Anak dapat mengembangkan bakat-bakatnya, anak dapat memupuk hobinya, sebaik- baiknya dan seluas-luasnya tanpa gangguan rasa takut. Karena semua kebutuhannya telah dipenuhi orang tuanya. (Partowisastro, 1983: 50-51).

Anak lahir dalam keadaan keadaan fitrah. Keluarga dan lingkungan anaklah yang mempengaruhi dan membentuk kepribadian, perilaku, dan kecendrungannya sesuai dengan bakat yang ada di dalam dirinya. Akan tetapi pengaruh yang kuat dan cukup langgeng adalah kejadian dan pengalaman pada masa kecil sang anak yang tumbuh dari suasana keluarga yang ia tempati. (Zurayk, 1995: 21).

Lebih jauh terkait pendidikan akhlak, keluarga memegang peranan yang sangat penting dalam pendidikan akhlak bagi anak-anak, sebagai institusi yang mula-mula sekali berinteraksi dengannya, oleh karena mereka mendapatkan pengaruh daripadanya atas segala tingkah lakunya. Keluarga harus dapat mengajarkan nilai dan faedah berpegang kepada akhlak semenjak kecil. Sebab manusia itu sesuai dengan sifat asasinya menerima nasehat jika datangnya melalui rasa cinta dan kasih sayang, sedangkan ia menolaknya jika disertai dengan kekasaran dan biadab. (Langgulung, 1995: 374) Hal ini bersesuaian dengan firman Allah SWT:

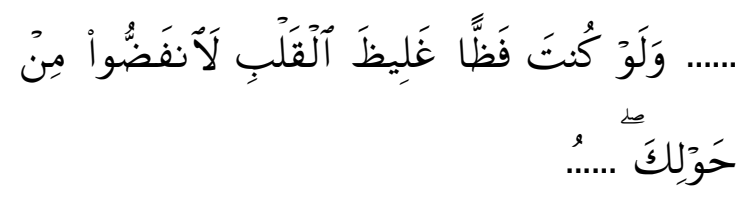

Artinya: "Jika Engkau (hai Muhammad) bersikap keras lagi berhati kasar, tentulah mereka akan menjauhkan diri dari sekelilingmu." (QS. Ali-Imran (3): 159).

Upaya penerapan akhlak yang mulia dalam kehidupan sehari-hari seharusnya menjadi bagian yang tak terpisahkan dari proses pendidikan 
akhlak baik dalam keluarga, maupun dalam masyarakat. Dalam keluarga metode aktivitas orang tua akan menjadi panutan bagi putra-putrinya. Akhlak yang mulia sebagaimana dikemukakan para ahli bukanlah terjadi dengan sendirinya, melainkan dipengaruhi oleh berbagai faktor, terutama lingkungan keluarga, pendidikan, dan masyarakat pada umumnya. Dengan demikian pembinaan akhlak putera-puteri terletak pada kedua orang tua. Hal ini ini antara lain yang dilakukan oleh Luqmanul Hakim terhadap puteraputerinya, sebagaimana dinyatakan dalam surat Luqman ayat 12 sampai dengan 19. Inti ajaran akhlak dalam ayat-ayat tersebut adalah 1) Larangan menyekutukan Allah; 2) Memuliakan kedua orang tua; 3) Merasa diawasi oleh Allah; 4) Mengerjakan shalat; 5) Menyuruh manusia berbuat baik dan mencegah berbuat munkar; akhlak yang demikian itu amat penting kita lakukan sepanjang hayat.

Juga dalam pandangan tokoh filsafat yang mengatakan bahwa tabiat atau akhlak tidak dapat diubah, seperti disebiutkan di atas tidak dapat dterima karena bertentangan dengan nash-nash al-Qur'an, as-Sunnah, akal, dan realitas kehidupan.

Segala ciptaan Allah terbagi kepada dua macam, pertama : Makhluk (ciptaan) yang tidak dapat diubah dengan usaha apapun, seperti langit, binatang-binatang, anggota tubuh dan bagian-bagian tubuh manusia. Kedua : makhluk yang dapat merubah perubahan dan dan kesempurnaan melalui latihan, disiplin dan pendidikan yang maksimum.( al-Ghazali, Mizan al amal dalam al Fikr akhlaq al Arabi, 1997, hlm. 178).

Akhlak merupakan salah satu yang dapat menerima perubahan. Hal ini sesuai dengan al-Qur'an dan as-
Sunnah. Dalam al-Qur'an Allah berfirman : "Dan (demi) jiwa serta penyempurnaannya (ciptaannya). Maka Allah mengilhamkan kepada jiwa itu (jalan) kefasikan dan ketakwaan. Sesungguhnya beruntunglah orang yang mensucikan jiwa itu. Dan sesungguhnya merugilah yang mengotorinya". (terjemahan al-Qur'an surat al-Syams 91 : 7-10) Sedangkan dalam salah satu hadits Nabi Muhammad s.a.w. beliau bersabda: "perbaikilah akhlakmu". (hadits ini dada disebutkan oleh alGhazali dalam kitabnya ihya ulumuddin. Menurut al Iraqi, pentakhrij hadis-hadis yang ada dalam kitab ihya ahsau akhalaqaqum diriwayatkan oleh $\mathrm{Abu}$ Bakr Bin Lal dalam kitab al Makarim al akhlak, dari hadist Mu'adz, yaitu had i st munqat i'dan rijalnya tsiqat. Baca alGhazali, Ihya ulumuddin,hlm. 72) Ini menunjukan bahwa pada perinsipnya akhlak yang buruk dapat diubah dan dididik sehingga menjadi akhlak yang baik. Karena seandainya akhlak seperti itu awal penciptaannya tanpa dapat mengalami perubahan apapun, maka tentu Nabi Muhammad s.a.w. tidak akan menyhuruh umat Islam untuk memperbaiki akhlak mereka.dan apabila akhlak tidak dapat berubah, maka sudah tentu pembinaan pelbagi institusi seperti pendidikan, undangundang, negara dan sebagainya menjadi tidak berguna. Sebab tujuan asas pembentukan institusi-institusi tersebut adalah untuk melahirkan generasi yang berakhlak mulia.

Ibnu Maskawayh menyebutkan bahwa syari'at berfungsi membiasakan manusia melakukan perbuatanperbuatan yang diridhai dan mempersiapkan mereka untuk menerima hikmah, mengusahakan kebaikan dan merealisasikan kebahagiandengan pemikiran yang benar dan analog yang tepat. (Miskawayh,Tahzib al-Akhlak, hlm. 35) 
Dengan demikian dapat dipastikan bahwa akhlak manusia bersifat resfonsif terhadap perubahan meskipun kadar upaya yang diperlukan dalam mendidik dan memperbaiki akhlak tidak sama pada setiap orang.

Ditinjau dari respon manusia terhadap pendidikan, maka al-Ghazali membagi manusia kepada empat kelompok. Pertama, manusia yang lalai dan tidak dapat membedakan antara kebaikan dengan keburukan. Mendidik orang seperti ini paling mudah. Jika ia dibimbing oleh seorang guru, maka akan baik budi pekertinya dalam waktu yang relatif singkat. Kedua, manusia yang dapat membedakan antara yang baik dengan yang buruk namun dia melakukan keburukan. Manusia seperti ini lebih sukar untuk dibentuk dari kelompok pertama. Ketiga, manusia yang berkeyakinan bahwa akhlakakhlak yang buruk merupakan kewajiban yang dianggap baik. Manusia seperti ini hampir saja tidak dapt lagi diobati. Dan keempat, manusia yang sejak kecilnya telah berkembang dalam keyakinan yang salah. Ia telah terbiasa dengan akhlak yang buruk dan merasa bangga dengannya. Manusia yang tergolong kedalam kelompok terakhir ini merupakan orang yang paling sukar untuk dididik atau diperbaiki akhlaknya. (Al-Ghazali, Mizan al-Amal, hlm. 178)

Kesempurnaan akhlak dapat dicapai dengan dua jalan. Pertama, melalui karuni Tuhan yang mencipta manusia dengan fitrah dan akal sempurna, akhlak yang baik, dan nafsu syahwat serta nafsu amarahnya senantiasa tunduk pada akal dan agama. Manusia tersebut dapat memperoleh ilmu tanpa belajar dan terdidik tanpa melalui proses pendidikan. Manusia yang tergolong dalam kelompok pertama ini dalah para Nabi dan Rasul Allah. Jalan kedua, akhlak tersebut diusahakan dengan cara mujahadah (berjuang secara bersungguh-sungguh) dan riya'adah (latihan) yaitu membiasakan diri melaakukan akhlakakhlak mulia. (Al-Ghazali, Ihya' ulumuddin, hal. 7475)

\section{Perspektif Imam Al-Ghazali tentang Urgensi Pendidikan akhlak Di Lingkungan Keluarga}

Mengenai pendidikan akhlak, keluarga memegang peranan penting sekali, karena dengan keluargalah anakanak mula-mula sekali berinteraksi dengannya. Oleh karena itu, anak mendapat pengaruh dari padanya atas segala tingkah lakunya, keluarga harus mampu mengajari mereka akhlak yang mulia, yang diajarkan Islam, seperti kebenaran, kejujuran, keikhlasan, kesabaran, kasih sayang, cinta, kebaikan pemurah dan lain-lain. Pentingnya akhlak ini, tidak hanya bagi diri sendiri bahkan akhlak anak itu menentukan eksistensi suatu bangsa. Seperti yang telah dipaparkan sebelumnya, seorang penyair Arab mengatakan bahwa ukuran suatu bangsa adalah moral (akhlak)nya. (Darajat, 9)

Dalam menerima pendidikan, manusia memiliki bermacam-macam tingkatan yang berbeda. Ada yang kasar, ada yang pemalu, pemarah, lemah lembut, ada yang cepat tanggap, ada yang tidak cepat tanggap, dan lain sebagainya. Perbedaan ini dapat dilihat pula pada orang-orang dewasa dalam menerima didikan budi pekerti utama. Perbedaan tabiat tersebut jikalau diabaikan begitu saja maka dia akan berkembang secara alamiah sesuai dengan tabiat yang dimilikinya. Dari sinilah kemudian Imam Al-Ghazali memandang perlunya pendidikan (agama/ akhlak). Agamalah yang dapat meluruskan anak-anak dan dapat mendidik mereka dengan perilaku terpuji dan mempersiapkan jiwa 
mereka untuk dapat menerima kebajikan. Di pundak orangtualah pendidikan agama (akhlak) ini. Dengan berbagai upaya, kalau perlu bahkan mempergunakan sanksi hukuman. Imam Al-Ghazali sendiri memperkenalkan sanksi dan balas jasa dalam pembinaan mental anak. (Sulaiman, 1993: 61).

Kalau dipahami bahwa agama akhirnya menuju kepada penyempurnaan berbagai keluhuran budi, maka pendidikan akhlak itu menjadi suatu hal yang teramat penting dalam pendidikan Islam. Anak-anak muslim harus mendapatkan pendidikan ini dari orang tuanya, sebab kalau tidak, anak akan menjadi nakal dan tidak akan memiliki akhlak (budi pekerti) yang luhur. (Fadjar, 1999: 4) Karena itu, peran orang tua dalam mendidik anak melalui pendidikan keagamaan yang benar adalah sangat penting. Dan di sini yang ditekankan adalah pendidikan dari orang tua bukan "pengajaran." Sebagian usaha pendidikan itu memang dapat dilimpahkan kepada lembaga pendidikan atau orang lain, seperti kepada sekolah dan guru agama misalnya. Tetapi sesungguhnya yang dapat dilimpahkan kepada lembaga atau orang lain terutama hanyalah pengajaran agama yang berwujud latihan dan pembelajaran membaca bacaan-bacaan keagamaan termasuk membaca Al-Qur'an dan mengerjakan ritus-ritus.

Dengan demikian Islam adalah merupakan agama yang sangat memperhatikan masalah pendidikan akhlak. Petunjuk kitab suci maupun sunnah Nabi dengan jelas menganjurkan kepada para pemeluknya untuk meningkatkan kecakapan dan akhlak generasi muda. Sebab pendidikan akhlak adalah merupakan sebuah investasi manusia untuk masa depan dengan membekali generasi muda budi pekerti luhur. Bahkan Al-Qur'an mengingatkan agar semua orang memelihara diri sendiri dan keluarga dari azab api neraka, yaitu dengan menanamkan taqwa kepada Allah SWT dan budi pekerti yang luhur:

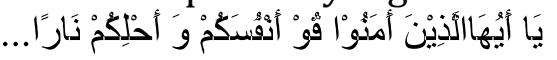
Artinya: "Hai orang-orang yang beriman, peliharalah dirimu dan keluargamu dari api neraka..." (QS. AtTahrim (66): 6.)

Keterangan ayat di atas menunjukkan bahwa Islam menyerukan kepada orang tua untuk memikul tanggung jawab terhadap anak-anak mereka. Islam telah membebani para bapak dan ibu suatu tanggung jawab yang sangat besar di dalam mendidik anak-anak dan mempersiapkan mereka dengan persiapan yang sempurna untuk menanggung beban hidup mereka. Penghianatan dan penyepelean terhadap tanggung jawab tersebut, diancam dengan azab yang berat seperti keterangan ayat di atas. (Ulwan, 2002: 149). Berkaitan dengan itu, Imam AlGhazali menegaskan bahwa bagaimanapun bapak itu menjaga anak dari api neraka lebih utama dari pada menjaganya dari api dunia. Untuk itu menurut Imam Al-Ghazali sang orang tua (keluarga) harus memberikan pendidikan akhlak kepada anakanaknya agar terhindar dari apa yang diterangkan Al-Qur'an tersebut. (AlGhazali, 1964: 193).

Pendapat Imam Al-Ghazali tentang keharusan keluarga memberikan pendidikan akhlak tersebut sejalan dengan keterangan yang bersumber dari Rasulullah SAW dalam sabdanya:

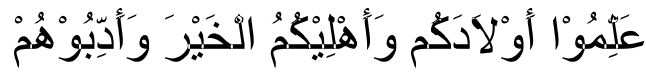
Artinya: "Ajarkanlah kebaikan (etika dan moral) kepada anak-anak kamu (laki-laki dan perempuan) dan keluargamu (isteri atau suami) dan 
didiklah mereka (pendidikan, olah pikir)." (Hadis Riwayat Abdur Razzaq dan Sa'id Ibn Mansur. Lihat juga Fuaduddin TM, Pengasuhan Anak, hlm. 20-21).

Adapun target dari pendidikan akhlak yaitu anak didik terbiasa dengan tatanan nilai dalam perilakunya, sehingga selalu dapat mengendalikan diri berpikir sebelum bertindak, yang pada akhirnya anak didik dapat membedakan antara yang baik dan yang buruk

Pendidikan akhlak dapat dilakukan dengan menetapkan pelaksanaan pendidikan agama baik di rumah, di sekolah maupun masyarakat. Hal demikian diyakini, karena inti ajaran agama adalah akhlak yang mulia yang bertumpu pada keimanan kepada Tuhan dan keadilan sosial. Zakiah Daradjat mengatakan, jika kita ambil ajaran agama, maka akhlak adalah sangat penting, bahkan yang terpenting, di mana kejujuran, kebenaran, keadilan dan pengabdian adalah di antara sifatsifat yang yang terpenting dalam agama. Hal ini sejalan pula dengan pendapat Fazlur Rahman dalam karyanya, Islam. Di situ ia mengatakan bahwa agama adalah akhlak yang bertumpu pada kepercayaan kepada Allah (hablum minallah), dan keadilan sosial (hablum minannas). (Rahman, 1987: 86).

Dari pernyataan di atas, pendidikan akhlak erat sekali hubungannya dengan pendidikan agama. Tidak berlebih-lebihan kalau kita katakan bahwa pendidikan akhlak dalam pengertian Islam adalah bagian yang tidak dapat dipisahkan dari pendidikan agama. Sebab agama jadi tolok ukur bagi kebaikan dan atau keburukan. Yang baik adalah yang dianggap baik oleh agama, dan sebaliknya yang buruk adalah apa yang dianggap buruk oleh agama. Sehingga nilai-nilai akhlak, keutamaan- keutamaan akhlak dalam masyarakat Islam adalah akhlak dan keutamaan yang diajarkan oleh agama. Seorang muslim tidak sempurna agamanya hingga agamanya menjadi baik. Para filosof Islam sepakat bahwa pendidikan akhlak adalah jiwa pendidikan Islam. Hal ini dikarenakan tujuan pendidikan Islam adalah mendidik jiwa dan akhlak. (Langgulung, 373.)

$$
\text { Adapun Imam Al-Ghazali }
$$
memahami hakekat pendidikan sebagai proses saling mempengaruhi antara fitrah manusia dengan lingkungan yang mengelilinginnya. (Sulaiman, 1993: 18). Pandangan Imam Al-Ghazali tersebut didasarkan pada pandangannya tentang alam. Imam Al-Ghazali membagi alam menjadi dua bagian yakni alam yang diciptakan secara sempurna dan tidak bisa diubah dan dialihkan, seperti bintang-bintang di langit dan organorgan tubuh dan yang kedua alam yang diciptakan tidak sempurna dan dapat dialihkan. Contoh untuk yang kedua adalah perangai manusia. Imam AlGhazali juga menjelaskan bahwa penyempurnaan dan pengalihan ini bukan berarti mengubah perangai manusia secara total dengan cara memaksakan. (Sulaiman, 1993: 69). Sehingga Imam Al-Ghazali dalam hal ini sangat menyadari adanya pengaruh lingkungan terhadap pertumbuhan dan perkembangan pribadi anak termasuk akhlak sang anak.

Imam Al-Ghazali juga merupakan tokoh yang berpandangan bahwa akhlak atau tingkah laku manusia itu dapat dibentuk dengan metode tertentu. Pandangannya ini berangkat dari pemikirannya pula yang menyatakan penolakan terhadap teori heriditas, yaitu teori yang menyatakan bahwa tingkah laku seseorang itu banyak dipengaruhi keturunan. Menurut Imam Al-Ghazali pengaruh keturunan terhadap akhlak seseorang 
itu ada, tetapi hanya sedikit, yang lebih banyak mempengaruhi adalah faktor pendidikan, faktor lingkungan dan masyarakat. (Jumbulati, 1994: 147).

Berkaitan dengan lingkungan pendidikan, Imam Al-Ghazali tidak menyebutkan secara eksplisit tentang tempat atau lembaga apa yang bertanggung jawab terhadap pembentukan akhlak. Namun lingkungan bagi Imam Al-Ghazali merupakan faktor yang sangat penting dalam rangka pencapaian tujuan pendidikan akhlak. Dalam hal ini lingkungan pendidikan berfungsi sebagai tempat transfer nilai, transfer ilmu pengetahuan dan tempat berinteraksi yang dapat saling mempengaruhi dalam pembentukan akhlak.

Berkaitan dengan pendidikan akhlak dalam keluarga, Imam AlGhazali, menilai bahwa anak adalah amanah Allah yang harus dijaga dan dididik untuk mencapai keutamaan dalam hidup dan mendekatkan diri kepada Allah. Semua bayi yang dilahirkan di dunia ini bagaikan sebuah mutiara yang belum diukur dan belum berbentuk amanat bernilai tinggi. Maka kedua orang tuanyalah yang akan mengukir dan membentuknya menjadi mutiara yang berkualitas tinggi dan berakhlak mulia. Maka ketergantungan anak kepada pendidiknya termasuk kepada orang tuanya akan tampak sekali. Kedekatan ayah ibu (orang tua) dengan anak, jelas memberikan pengaruh yang paling besar dalam proses pendidikan (pembentukan) akhlak, dibanding pengaruh yang diberikan oleh komponen pendidikan lainnya. Karena ikatan ibu bapak dengan putera puterinya adalah lebih kuat daripada ikatan persaudaraan dan ikatan lainnya. (Al-Ghazali, 1964: 128).

Imam Al-Ghazali menegaskan bahwa tiap-tiap anak itu dilahirkan, dalam keadaan kelurusan, sehat kejadiannya (fitrah)nya. Ibubapaknyalah yang membuatnya menjadi Yahudi atau Nasrani atau Majusi. (Al-Ghazali, 1995: 94). Atau dengan kata lain Ibu bapaknyalah yang membawa anak itu, condong kepada salah satu dari dua segi tersebut. (AlGhazali, 1964: 198).

Lebih spesifik, di dalam Ihya $\bar{a}^{\prime}$ Ulūmuddīn pada bahasan tentang cara melatih budi pekerti yang baik pada anak Imam Al-Ghazali mengatakan: "Ketahuilah, bahwa cara melatih anak itu sangat penting dan amat perlu. Anak adalah mutiara yang sangat berharga bagi kedua orang tuanya. Hati yang suci adalah mutiara yang sangat berharga, halus, dan bersih dari ukiran dan gambaran. Ia menerima semua yang diukir padanya. Dan terpengaruh kepada semua yang dipengaruhkan padanya." (Al-Ghazali, 1964: 198).

Dari ungkapan di atas tergambar betapa besar pengaruh lingkungan yang bukan hanya terbatas pada unsur manusia, namun unsur makanan juga dapat mempengaruhi pembentukan akhlak anak. Menanggapi hal ini, Imam Al-Ghazali mengatakan bahwa hendaklah anak diawasi dari awal kelahirannya, jangan diserahkan kepada wanita sembarangan (tidak saleh) untuk menyusuinya. Anak harus diserahkan kepada wanita yang saleh, beragama dan makan makanan yang halal untuk diasuh dan disusui. Karena susu yang bersumber dari yang haram, tidak mempunyai berkah. Apabila pertumbuhan anak itu terjadi dari susu yang demikian, niscaya melekatlah kejadiannya dari yang keji. Lalu perilakunya condong kepada yang bersesuaian dengan yang keji-keji itu. (Al-Ghazali, 1964: 198).

Pendidikan akhlak dalam keluarga menurut Imam Al-Ghazali sangat besar pengaruhnya terhadap budi pekerti 
anak ke depannya. Sehingga menurutnya bukan saja orang yang tidak punya cacad budi pekerti yang bisa dikembangkan dan dibentuk, anak yang berakhlak buruk pun bisa diubah melalui pendidikan akhlak terlebih dalam lingkup keluarga. Sehubungan dengan ini Imam Al-Ghazali menunjukkan suatu cara memperbaiki akhlak anak yang buruk melalui pendidikan. Di dalam Ihyā' Ulümuddīn ia menegaskan: "Anak itu jika disia-siakan pada permulaan pertumbuhannya, niscaya menurut yang kebanyakan, anak itu keluar dengan buruk akhlak, pendusta, pendengki, suka memintaminta, banyak perkataan sia-sia, suka tertawa, menipu dan banyak senda gurau. Sesungguhnya yang demikian itu, dapat dijaga dengan baiknya pendidikan. Kemudian disibukkan (dimasukkan) ia ke madrasah, maka (di sana) ia mempelajari Al-Qur'an dan hadis-hadis yang mengandung ceritacerita, riwayat dan hal-ihwal orang baik-baik. Supaya tertanam dalam jiwanya kecintaan kepada orang-orang shalih." (Al-Ghazali, 1964: 195).

Sebelum anak dapat berpikir logis dan memahami hal yang abstrak atau belum memahami mana yang baik dan mana yang buruk dengan jelas (tamyiz). Latihan dan kebiasaan (habit forming) mempunyai peranan yang sangat dominan dalam pembinaan akhlak anak, karena masa itu merupakan saat yang tepat untuk menanamkan dasar akhlak yang mulia. Lagi-lagi keluargalah yang memegang peranan untuk ini.

$$
\text { Imam Al-Ghazali sangat }
$$

menganjurkan agar dalam pembinaan akhlak anak dilakukan dengan cara latihan-latihan dan pembiasaanpembiasaan yang sesuai dengan perkembangan jiwa dan akalnya. Hal ini seakan-akan dipaksakan agar anak itu terhindar dari kebiasaan yang menyesatkan. (Zainuddin: 107) Oleh karena pembiasaan dan latihan akan membentuk sikap tertentu pada anak, yang lambat laun sikap itu akan bertambah jelas dan kuat. Akhirnya tidak tergoyahkan karena telah masuk menjadi bagian dari kepribadian. Sehingga Imam Al-Ghazali menyatakan: "Jika anak itu sejak tumbuhnya sudah dibiasakan dan diajari yang baik-baik, maka nantinya ketika ia mencapai usia baligh tentulah ia akan dapat mengetahui rahasianya yakni mengapa perbuatan yang tidak baik itu dilarang oleh ayah (orang tua)." (Al-Ghazali, 1964: 193).

Imam Al-Ghazali, lebih jauh berpandangan pendidikan akhlak harus diajarkan dalam keluarga agar anggota keluarga terutama anak terhindar dari apai neraka, kemudian anak tersebut harus dijaga dari pergaulan yang jahat serta jangan dibiasakan mewah. (Said, t.t: 29). Pandangan Imam Al-Ghazali ini didasarkan pada firman Allah SWT dalam surat At-Tahrim (66) ayat 6 tentang perintah Allah agar memelihara keluarga dari neraka, yang dicantumkannya dalam Ihy $\bar{a}^{\prime}$ Ulūmuddīn. (Al-Ghazali, 1964: 193).

Berkaitan dengan hal di atas, Imam Al-Ghazali beranggapan bahwa melatih anak-anak untuk berakhlak yang baik, pada dasarnya adalah tanggung jawab orang tua mereka. Imam Al-Ghazali menekankan dalam pendidikan akhlak anak dengan melindungi mereka dari pergaulan buruk, karena menurut Imam AlGhazali hal tersebut merupakan dasar (ashl) latihan bagi anak-anak untuk berakhlak yang baik. Hal ini karena sebagian besar pengajaran untuk anakanak adalah melalui peniruan. Pengetahuan tentang manfaat dan mudarat dari sifat-sifat baik dan buruk bagi akhirat tidak relevan dalam latihan moral pada masa kanak-kanak, karena akal mereka belum bisa memikirkan hal 
seperti itu. (Quasem dan Kamil, 1988: 102-103).

Dari paparan tersebut, membuktikan bahwa Imam Al-Ghazali berpandangan bahwa lingkungan keluarga sangat dominan dalam pembentukan akhlak al-karimah. Menurut Imam Al-Ghazali keluarga memegang peranan penting dalam pendidikan akhlak. Dengan demikian dapat dikatakan bahwa menurut Imam Al-Ghazali pendidikan akhlak sangat urgen dalam lingkungan keluarga demi tercapainya kehidupan yang sakinah, mawaddah dan warahmah.

\section{SIMPULAN}

Imam Al-Ghazali sangat menekankan aspek akhlak dalam sistem pendidikannya karena menurutnya tujuan pendidikan agama adalah pendidikan akhlak itu sendiri. Pendidikan akhlak menurut Imam AlGhazali merupakan suatu proses pembentukan manusia yang memiliki jiwa yang suci, kepribadian yang luhur yang bertujuan untuk mendekatkan diri kepada Allah. Adapun sumber pendidikan akhlak menurut Imam AlGhazali adalah wahyu (Al-Qur'an dan Hadis) dengan perantara bimbingan yang ketat dari guru pembimbing rohani (syaikh). Sedangkan dalam hal materi pendidikan akhlak, Imam AlGhazali sangat mementingkan ilmuilmu yang bertalian erat dengan agama walaupun tidak mengesampingkan ilmu pengetahuan umum lainnya.

Menurut Imam Al-Ghazali pendidikan akhlak merupakan tonggak pertama perubahan masyarakat. Bagi Imam Al-Ghazali pendidikan akhlak atau pendidikan budi pekerti luhur yang berdasarkan agama inilah yang harus dimulai oleh ibu-bapak di lingkungan rumah tangga. Di lingkungan keluarga harus dimulai pembinaan kebiasaan-kebiasaan baik, dalam diri anak-anak. Lingkungan rumah tanggalah menurut Imam AlGhazali yang sangat dominan dalam membina pendidikan akhlak, karena anak yang berusia muda dan kecil itu lebih banyak di lingkungan rumah tangga dari pada di luar. Kemudian ikatan ibu bapak dengan puteraputerinya adalah lebih kuat daripada ikatan persaudaraan dan ikatan lainnya sehingga jelas akan memberikan pengaruh yang paling besar dalam proses pendidikan akhlak, dibanding pengaruh yang diberikan oleh komponen pendidikan lainnya. Secara umum menurut Imam Al-Ghazali keluarga memegang peranan penting dalam pendidikan akhlak. Dengan demikian dapat dikatakan bahwa menurut Imam Al-Ghazali pendidikan akhlak sangat urgen dalam lingkungan keluarga.

\section{DAFTAR RUJUKAN}

Abdullah, M. Amin. 2002. Antara AlGhazali dan Kant: Filsafat Etika Islam, alih bahasa Hamzah. Bandung: Mizan.

Abdullah, Mansur Thoha. 2003. Kritik Metodologi Hadis Tinjauan Atas Kontroversi Pemikiran Imam AlGhazali. Yogyakarta: Pustaka Rihlah.

Ahmad, Zaenal Abidin. 1975. Riwayat Hidup Imam Al-Ghazali. Jakarta: Bulan Bintang.

Al-Ghazali, Abu Hamid. tt. Ihyā' Ulūmuddīn, Juz III, Beirut: Dārul Kitabil Islamiy. . 1964. Ihyā' Ulūmuddīn, Jilid III dan $I V$, alih bahasa Ismail Ya'kub, Surabaya: Faisan.

1995. Mizan al-'Amal, alih bahasa A. Musthofa, cet. I, Jakarta: Rineka Cipta. 
1997. Mukhtashar Ihyā'

Ulūmuddīn, alih bahasa Irawan Kurniawan, Cet. II, Bandung: Mizan.

Al Jumbulati, Ali. 1994. Perbandingan Pendidikan Islam, alih bahasa M. Arifin. Jakarta: Rineka Cipta.

Amien, Miska Muhammad. 1983. Epistemologi Islam: Pengantar Filsafat Pengetahuan Islam, cet. I. Jakarta, Universitas Indonesia Press.

Asmaran As.1992. Pengantar Studi Akhlak. Jakarta: Rajawali Press dan LSIK.

1994. Pengantar Studi Tasawuf, cet. I Jakarta: RajaGrafindo Persada.

Azra, Azyurmardi. 1999. Pendidikan Islam, Tradisi dan Modernisasi Menuju Millenium Baru. Jakarta: Logos.

Boediono dkk., 2000. Pengkajian dan Pengembangan Kurikulum Pendidikan Budi Pekerti, dalam Jurnal Pendidikan dan Kebudayaan, No. 021, Tahun ke-5., Jakarta: Badan Penelitian dan Pengembangan Departemen Pendidikan Nasional.

Dahlan, Abdul Aziz, dkk., "Filsafat," Ensiklopedi Islam, Jakarta: Ichtiar Baru van Hoeve, 2000.

Darajat, Zakiah. 1976. Membina Nilainilai Moral di Indonesia. Jakarta: Bulan Bintang.

Departemen Agama. 1992. Al-Qur'an dan Terjemahnya. Semarang, Toha Putra.

Fadjar, Malik. 1999, Reorientasi Pendidikan Islam. Jakarta: Fajar Dunia.

Fuaduddin TM., 1999. Pengasuhan Anak dalam Keluarga Islam, cet. I. Jakarta: Lembaga Kajian Agama dan Jender.

Hanafi, A., 1976. Filsafat Islam. Jakarta: Bulan Bintang.
Held, Virginia. 1991. Etika Moral Pembenaran Tindakan Sosial. Jakarta: Erlangga.

Kholiq, Abdul, dkk., 1999. Pemikiran Pendidikan Islam Kajian Tokoh Klasik dan Kontemporer. Yogyakarta: Pustaka Pelajar.

Langgulung, Hasan. 1995. Manusia dan Pendidikan: Suatu Analisa Psikologi dan Pendidikan, cet. III., Jakarta: Al Husna Zikra.

Madjidi, Busyairi. 1997. Konsep Kependidikan Para Filosof Muslim, Cet. I. Yogyakarta: Al Amin Press.

Nasution, Harun. 1998. Islam Rasional: Gagasan dan Pemikiran Prof. DR. Harun Nasution. Bandung: Mizan.

1999. Perlunya

Menghidupkan Kembali

Pendidikan moral", dalam

Pendidikan Agama dalam

Perspektif Agama-agama.

Yogyakarta: tp.

Nasution, Muhammad Yasir. 1996. Manusia Menurut Al-Ghazali, cet. I. Jakarta: RajaGrafindo Persada.

Partowisastro,Koestoer.

1983.

Dinamika Psikologi Sosial, cet. I. Jakarta: Erlangga.

Quasem, M. Abul dan Kamil. 1988. Etika Al-Ghazali: Etika Majemuk Di dalam Islam. Bandung: Pustaka.

Rahim, Husni. 2001. Arah Baru Pendidikan Islam di Indonesia. Jakarta: Logos.

Rahman, Fazlur. 1987. Islam, alih bahasa Senoaji Saleh, Cet. I. Jakarta: Bina Aksara.

Rusn, Abidin Ibnu. 1998. Pemikiran AlGhazali tentang Pendidikan. cet. I, Yogyakarta: Pustaka Pelajar.

Said, M., t.t. Imam Al-Ghazali tentang: Falsafah Akhlak, cet. ke-5. Bandung: Al-Ghazalil-Ma'arif.

Sulaiman, Fathiyyah Hasan. 1993. Aliran-aliran dalam Pendidikan: Studi Tentang Aliran Pendidikan Menurut Al-Ghazali, alih bahasa 
Agil Husain Al-Munawar dan Hadri Hasan, Semarang: Dina Utama.

Syafi'i, Imam. 1992. Konsep Guru Menurut Al-Ghazali: Pendekatan Filosofis Pedagogis, Cet. I. Yogyakarta: Duta Pustaka.

Ulwan, Abdullah Nasih. 2002. Pendidikan Anak dalam Islam, alih bahasa Jamaluddin Miri, Cet. ke-3. Jakarta: Pustaka Amani.

Zainuddin dkk., 1991. Seluk-Beluk Pendidikan Dari Al-Ghazali. Jakarta: Bumi Aksara.
Zakaria, Teuku Ramli, Pendidikan Budi Pekerti, dalam Jurnal Pendidikan dan Kebudayaan, No. 021, Tahun ke-5, Jakarta: Badan Penelitian dan Pengembangan Departemen Pendidikan Nasional, Januari 2000.

Zurayk, Ma'ruf. 1995. Aku dan Anak, Bimbingan Praktis Mendidik Anak Menuju Remaja, alih bahasa M. Syaifuddin dkk., Bandung: AlBayan. 